\title{
PENGARUH PENDEKATAN SAINTIFIK TERHADAP KEMAMPUAN BERPIKIR KRITIS MAHASISWA
}

\author{
Chrisnaji Banindra Yudha \\ Pendidikan Matematika, STKIP Kusuma Negara \\ chrisnaji_by@stkipkusumanegara.ac.id
}

\begin{abstract}
Abstrak
Penelitian ini adalah penelitian kuantitatif dengan jenis true experimental design dengan model desain pretest-posttest control group design. Penelitian ini dilaksanakan di Prodi PGSD Semester ganjil 2018/2019 pada mata kuliah pendidikan matematika SD 2. Populasi dalam penelitian ini adalah 60 Mahasiwa. Sampel yang digunakan dalam penelitian ini adalah 40 siswa, 20 siswa untuk kelas eksperimen dan 20 siswa untuk kelas kontrol. Instrument penelitian ini menggunakan tes kemampuan berpikir kritis dan lembar observasi untuk guru dan siswa yang masing-masing telah divalidasi oleh ekpert judgement. Data yang diperoleh dianalisis dengan uji normalitas dan uji homogenitas kemudian dilanjutkan dengan uji hipotesis menggunakan uji-t. Hasil penelitian menunjukkan bahwa: (1) Penerapan pendekatan saintifik terhadap kemampuan berpikir kritis mahasiswa mengalami peningkatan secara berkelanjutan dengan kategori penilaian baik. (2) kemampuan berpikir kritis berimbas pada Hasil belajar matematika setelah diterapkan pendekatan saintifik dengan kategori tinggi. Begitu juga pada kelas yang menerapkan metode pembelajaran konvensional, juga mengalami peningkatan hasil belajar akan tetapi peningkatannya dengan kategori sedang. (3) Ada pengaruh positif dan signifikan penerapan pendekatan saintifik terhadap kemampuan berpikir kritis mahasiswa PGSD STKIP Kusuma Negara Semester Ganjil 2018/2019.
\end{abstract}

Kata Kunci: Pendekatan Saintifik, Berpikir Kritis, Matematika

\section{PENDAHULUAN}

Pembelajaran matematika diberikan kepada mahasiswa Pendidikan Guru Sekolah Dasar (PGSD). Materi matematika yang disampaikan terdiri dari konsep dasar matematika sampai dengan penerapan pembelajaran matematika untuk mengajar di SD. Para calon guru SD diwajibkan memiliki ilmu matematika ke SDan yang mumpuni, sebab dalam profesinya sebagai guru SD, mereka menjadi penanam ilmu matematika bagi generasi penerus Bangsa Indonesia yang pertama. Dengan demikian para calon atau guru SD sebaiknya menguasai materi matematika SD.

Menurut Ibrahim (2012: 5) "matematika adalah ilmu tentang pola dan hubungan, sebab dalam matematika sering dicari keseragaman seperti keterurutan, dan keterkaitan pola dari sekumpulan konsep-konsep tertentu atau modelmodel yang merupakan representasinya, sehingga dapat dibuat generalisasinya untuk selanjutnya dibuktikan kebenarannya secara deduktif." Dalam memahami konsep matematika dibutuhkan analisa yang mendalam dari pada ilmu yang lain dan siswa sering mengalami dan menemui kesulitan. Pembelajaran matematika dapat bermakna apabila mahasiswa yang menemukan sendiri konsep yang telah dipelajari (Chrisnaji Banindra Yudha, 2018: 13).
Matematika membentuk pola pikir yang memelajarinya diantaranya berpikir logis, analitis, sistematis, kritis dengan penuh kecermatan (Chrisnaji Banindra Yudha, 2014: 1). matematika bukan merupakan pembelajaran menggunakan rumus saja, akan tetapi pembelajaran matematika memberikan tekanan pada aktivitas manusia, sikap minat, dan kemampuan berbahasa. Dalam memahami konsep matematika dibutuhkan analisa yang mendalam dari pada ilmu yang lain dan siswa sering mengalami dan menemui kesulitan (Chrisnaji Banindra Yudha, 2018: 208)

Konsepsi berpikir kritis berasal dari dua kata dasar dalam bahasa Latin yakni "kriticos" yang berarti penilaian yang cerdas (discerning judgment) dan "criterion" yang berarti standar. Kata kritis juga ditandai dengan analisis cermat untuk mencapai penilaian yang objektif terhadap sesuatu. Dengan demikian, berpikir kritis berarti berpikir untuk menghasilkan penilaian, pendapat atau evaluasi yang objektif dengan menggunakan standar evaluasi yang tepat untuk menentukan kebaikan, manfaat serta nilai sesuatu (Emi Emilia, 2007).

Konsep berpikir kritis dapat diketahui melalui dua sudut pandang, yakni konsepsi umum dan konsepsi subjekspesifik. Konsepsi umum memandang sebagai satu set 
kemampuan dan disposisi yang bisa digeneralisasi dan dapat diterapkan dalam berbagai situasi dan kondisi dan berbagai domain pengetahuan. Sementara itu, konsepsi subjek-spesifik menganggap sebagai satu bentuk berpikir yang spesifik dalam kerangka kognitif tertentu, tergantung pada dan ditentukan oleh pengetahuan yang luas mengenai masalah yang dipikirkannya (Emi Emilia, 2007).

Berpikir kritis adalah proses yang terjadi pada seseorang untuk menjawab pertanyaan dengan informasi yang tersedia (Inch, 2006). Indikator keterampilan berpikir kritis antara lain mampu melakukan analisis (Liliasari, 2005). Yildirim (2011) mendefinisikan berpikir kritis adalah "suatu proses dalam mencari, memperoleh, mengevaluasi, menganalisis, mensintesis dan konseptualisasi informasi sebagai panduan untuk mengembangkan pemikiran seseorang dengan kesadaran diri, dan kemampuan untuk menggunakan informasi". Facione (1995) menyatakan bahwa indicator berpikir kritis adalah kemampuan dalam interpretasi, analisis, melakukan inferensi, memberikan penjelasan explanation, kemampuan mengevaluasi dan melakukan pengaturan diri. Adapun indicator berpikir kritis adalah 1).Interpretasi 2).Analysis 3). Evaluation 4).Inference 5).Explanation 6).Self-Regulation.

Menurut Kowiyah (2012) berpikir kritis adalah 1) Suatu sikap mau berpikir secara mendalam tentang masalah-masalah dan hal-hal yang berada dalam jangkauan pengalaman seseorang. 2) Pengetahuan tentang metodemetode pemeriksaan dan penalaran yang logis. 3) Semacam suatu ketrampilan untuk menerapkan metodemetode tersebut. 4) Sedangkan menurut Ali Hamzah dan Muhlisrarini berpikir kritis secara umum dianggap sebagai proses kognitif, tindakan mental, untuk memperoleh pengetahuan. 5) Suatu kegiatan untuk mencapai pengetahuan, di mana melalui kegiatan berpikir manusia dapat mengkaji benda-benda, gejala-gejala, dan peristiwa sehingga diperoleh kesimpulan sebagai suatu pengetahuan.

Seifert dan Hoffnung (Desmita. 2011) menyebutkan beberapa komponen berpikir kritis, yaitu :

1) Basic operations of reasoning. Untuk berpikir secara kritis, seseorang memiliki kemampuan untuk menjelaskan, menggeneralisasi, menarik kesimpulan deduktif dan merumuskan langkahlangkah logis lainnya secara mental.

2) Domain-specific knowledge. Dalam menghadapi suatu problem, seseorang harus mengetahui tentang topik atau kontennya. Untuk memecahkan suatu konflik pribadi, seseorang harus memiliki pengetahuan tentang person dan dengan siapa yang memiliki konflik tersebut.

3) Metakognitive knowledge. Pemikiran kritis yang efektif mengharuskan seseorang untuk memonitor ketika ia mencoba untuk benar-benar memahami suatu ide, menyadari kapan ia memerlukan informasi baru dan mereka-reka bagaimana ia dapat dengan mudah mengumpulkan dan mempelajari informasi tersebut.

4) Values, beliefs and dispositions. Berpikir secara kritis berarti melakukan penilaian secara fair dan objektif. Ini berarti ada semacam keyakinan diri bahwa pemikiran benar-benar mengarah pada solusi. Ini juga berarti ada semacam disposisi yang persisten dan reflektif ketika berpikir.

Berpikir kritis melibatkan tujuan, goal-directed berpikir dalam proses pembuatan keputusan berdasarkan bukti dan bukan menebak dalam proses pemecahan masalah ilmiah Nugent dan Vitale (Fahim \& Pezeshki 2012). Ini melibatkan penalaran logis, kemampuan untuk fakta terpisah dari pendapat, memeriksa hal-hal sebelum menerima mereka dan mengajukan pertanyaan diri sendiri sepanjang waktu (Wood, 2002). Selain itu, proses dari penalaran formal itu sendiri meliputi beberapa proses. Nugent dan Vitale (2008) menjelaskan beberapa proses penalaran formal yang menggabungkan pemikiran kritis sebagai berikut.

1) Pemecahan Masalah-melibatkan identifikasi masalah, mengeksplorasi alternatif intervensi, menerapkan intervensi yang dipilih, dan tiba tujuan akhir, yang merupakan.

2) Pengambilan Keputusan-dilakukan dengan hati-hati meninjau informasi yang solusi untuk masalah ini. signifikan, menggunakan metode penalaran, dan tiba di tujuan akhir, yang merupakan keputusan.

3) Penalaran Diagnostik melibatkan pengumpulan informasi, menghubungkan informasi yang dikumpulkan dengan standar, mengidentifikasi makna dari informasi yang dikumpulkan, dan tiba tujuan akhir, yang merupakan diagnosis kesimpulan.

4) Metode Ilmiah melibatkan kegiatan mengidentifikasi masalah yang harus diselidiki mengumpulkan data, merumuskan hipotesis, pengujian hipotesis melalui eksperimen, mengevaluasi hipotesis, dan tiba di tujuan akhir, yang merupakan penerimaan atau penolakan hipotesis.

Jika pengajaran keterampilan berpikir kritis kepada peserta didik belum sampai pada tahap peserta didik dapat mengerti dan belajar menggunakannya, maka keterampilan berpikir tidak akan banyak bermanfaat. Pembelajaran yang efektif dari suatu keterampilan memiliki empat komponen, yaitu: identifikasi komponen-komponen prosedural, instruksi dan pemodelan langsung, latihan terbimbing, dan latihan bebas..

Menurut Ennis (Hilaria, 2017) bahwa orang yang berpikir kritis, idealnya memliki kecenderungan sebagai berikut: 1. Peduli pada kebenaran dari apa yang mereka yakini, dan dapat memberikan alasan mengapa ia meyakinkan hal tersebut. Mereka selalu ingin memahami 
secara benar. 2. Peduli pada kejujuran dan kejelasan dalam berbicara 3. Peduli untuk menghormati dan menghargai setiap orang Menurut Ennis (Hilaria, 2015). Karakteristik berpikir kritis menurut Ennis (2011) kriteria orang berpikir kritis disingkat FRISCO (Focus, Reason, Inference, Situation, Clarity, Overview).

Tabel 1. Kriteria Berpikir Kritis

\begin{tabular}{|c|c|}
\hline $\begin{array}{c}\text { Kriteria } \\
\text { Berpikir Kritis }\end{array}$ & Indikator \\
\hline Focus & $\begin{array}{l}\text { Siswa memahami permasalahan } \\
\text { pada soal yang diberikan. }\end{array}$ \\
\hline Reason & $\begin{array}{l}\text { Siswa memberikan alasan } \\
\text { berdasarkan fakta/bukti yang } \\
\text { relevan pada setiap langkah dalam } \\
\text { membuat keputusan maupun } \\
\text { kesimpulan. }\end{array}$ \\
\hline Inference & $\begin{array}{l}\text { 1. Siswa membuat kesimpulan } \\
\text { dengan tepat. } \\
\text { 2. Siswa memilih reason (R) } \\
\text { yang tepat untuk mendukung } \\
\text { kesimpulan yang dibuat. }\end{array}$ \\
\hline Situation & $\begin{array}{l}\text { Siswa menggunakan semua } \\
\text { informasi yang sesuai dengan } \\
\text { permasalahan. }\end{array}$ \\
\hline Clarity & $\begin{array}{ll}\text { 1. } & \text { Siswa menggunakan } \\
\text { penjelasan yang lebih lanjut } \\
\text { tentang apa } \\
\text { dimaksudkan } \\
\text { kesimpulan yang dibuat. } \\
\text { dalam }\end{array}$ \\
\hline Overview & $\begin{array}{l}\text { Siswa meneliti atau mengecek } \\
\text { kembali secara menyeluruh mulai } \\
\text { dari awal sampai akhir (yang } \\
\text { dihasilkan FRISC) }\end{array}$ \\
\hline
\end{tabular}

Pendekatan saintifik pertama kali diperkenalkan ke ilmu pendidikan Amerika. Adapun waktunya kurang lebih pada akhir abad ke-19, fokusnya pada pendekatan laboratorium kemiliteran yang mengarah pada fakta-fakta ilmiah.

Karakteristik Pendekatan saintifik adalah doing science. Pendekatan saintifik juga berkembang pada matematika. Scientific Mathematics merupakan proyek Eropa yang mengaitkan antara matematika dan ilmu pengetahuan. Hal ini bertujuan untuk mengembangkan pembelajaran ke arah belajar yang komprehensif dan multidimensional tentang isi dan konsep matematika. Ide dasarnya adalah untuk mendorong pembelajaran matematika dalam konteks ilmiah dan kegiatan peserta didik Beckmann (Anisa Rara Triyaningsih, 2015: 25). Pendekatan ini memudahkan pengajar atau pengembang kurikulum untuk memperbaiki proses pembelajaran, yaitu dengan memecah proses kedalam langkah-langkah atau tahapan-tahapan secara terperinci yang memuat instruksi untuk peserta didik melaksanakan kegiatan pembelajaran Varelas M and Ford M (Anisa Rara Triyaningsih, 2015: 25). Belajar dengan melakukan kegiatan berkontribusi kepada pemahaman intuitif matematika peserta didik. Dengan kata lain,belajar matematika yang baik adalah mengalami. Hosnan (Mega Selvira Paut 2016: 2) menjelaskan bahwa pendekatan saintifik dimaksudkan untuk memberikan pemahaman kepada peserta didik dalam mengenal dan memahami berbagai materi menggunakan pendekatan ilmiah, bahwa informasi bisa berasal dari mana saja, kapan saja dan tidak bergantung pada informasi searah dari guru. Penerapan pendekatan saintifik dalam pembelajaran melibatkan keterampilan proses seperti mengamati, menanya, mencoba, menalar, dan mengkomunikasikan.

Penggunaan pendekatan saintifik dalam pembelajaran bertujuan untuk mencapai suatu kompetensi. Harapannya setelah pembelajaran akan terjadi perkembangan kreativitas siswa, rasa ingin tahu siswa meningkat, siswa mampu mengajukan pertanyaan, dan mempunyai keterampilan berpikir kritis sehingga mempunyai manfaat dalam hidupnya (Depdiknas, 2013).

Deskripsi langkah-langkah pendekatan saintifik pada pembelajaran kurikulum 2013 menurut (Yani, 2014) adalah sebagai berikut: (1). Mengamati: Membaca, mendengar, menyimak, melihat (tanpa atau dengan alat) untuk mengidentifikasi hal-hal yang ingin diketahui . Mengamati dengan indra (membaca, mendengar, menyimak, melihat, menonton, dan sebagainya) dengan atau tanpa alat. (2). Menanya: Mengajukan pertanyaan tentang hal-hal yang tidak dipahami dari apa yang diamati atau pertanyaan untuk mendapatkan informasi tambahan tentang apa yang diamati. Membuat dan mengajukan pertanyaan, tanya jawab, berdiskusi tentang informasi yang belum dipahami, informasi tambahan yang ingin diketahui, atau sebagai klarifikasi. (3). Mencoba/mengumpulkan data (informasi): Melakukan eksperimen, membaca sumber lain dan buku teks, mengamati objek/kejadian/aktivitas, wawancara dengan narasumber. Mengeksplorasi, mencoba, berdiskusi, mendemonstrasikan, meniru bentuk/gerak, melakukan eksperimen, membaca sumber lain selain buku teks, mengumpulkan data dari narasumber melalui angket, 
wawancara, dan memodifikasi.

Mengasosiasikan/mengolah informasi: Mengolah informasi yang sudah dikumpulkan baik terbatas dari hasil kegiatan mengumpulkan/eksperimen maupun hasil dari kegiatan mengamati dan kegiatan mengumpulkan informasi, mengolah informasi yang sudah dikumpulkan, menganalisis data dalam bentuk membuat kategori, mengasosiasi atau menghubungkan fenomena/informasi yang terkait dalam rangka menemukan suatu pola, dan menyimpulkan. (5). Mengkomunikasikan: Menyampaikan hasil pengamatan, kesimpulan berdasarkan hasil analisis secara lisan, tertulis, atau media lainnya. Menyajikan laporan dalam bentuk bagan, diagram, atau grafik; menyusun laporan tertulis; dan menyajikan laporan meliputi proses, hasil, dan kesimpulan secara lisan.

\section{METODE}

Jenis penelitian yang digunakan yakni peneilitian kuantitatif jenis True Experimental. Penelitian ini dirancang untuk mendapatkan pengaruh penerapan pendekatan saintifik terhadap kemampuan berpikir kritis mahasiswa PGSD STKIP Kusuma Semester ganjil 2018/2019. Desain penelitian yang digunakan dalam true experimental ini adalah pre-test post-test control group design yang menurut Sugiono (2010) melibatkan dua kelompok yaitu satu kelompok sebagai kelompok kontrol dan satu sebagai kelompok eksperimen. Pada desain ini kelompok eksperimen maupun kelompok kontrol dipilih secara random atau acak. Kelompok eksperimen dalam penelitian ini adalah kelompok yang diberikan perlakuan penerapan pendekatan saintifik. Adapun kelompok kontrol adalah kelompok yang tidak diberikan perlakuan penerapan pendekatan saintifik. Pada pembelajaran kelompok eksprimen dan kelompok kontrol dilaksanakan pretest saat awal pembelajaran dan dilanjutkan dengan pemberian perlakuan berupa penerapan pendekatan saintifik dan terakhir diberikan posttest. Pada kelompok kontrol yang membedakannya dengan kelompok kelas eksprimen yakni tidak adanya pemberian perlakuan penerapan pendekatan saintifik. Adapun desain penelitiannya dapat dilihat pada Tabel 2 berikut.

Tabel 2. Desain Penelitian Nonequivalent Control Group Design

\begin{tabular}{|c|c|c|c|}
\hline Kel. & Pretest & Perlakuan & Postest \\
\hline $\mathrm{E}$ & $\mathrm{O} 1$ & $\mathrm{X}$ & $\mathrm{O} 2$ \\
\hline $\mathrm{K}$ & $\mathrm{O} 2$ & - & $\mathrm{O} 4$ \\
\hline
\end{tabular}

Populasi yang dipilih sebagai subyek dalam penelitian ini adalah seluruh. Adapun jumlah populasi dalam penelitian ini sebanyak 60 mahasiswa. Jumlah sampel masing-masing antara 10 sampai 20 dari keseluruhan populasi” (Sugiyono, 2016: 91) adapun Sampel dalam penelitian adalah 40 siswa, masing-masing terdiri dari 20 siswa kelompok eksperimen sedangkan kelompok kontrol juga terdiri dari 20.

Teknik pengumpulan data yang digunakan terdiri atas dua yaitu tes dan observasi. Pemberian tes ini dilakukan dalam bentuk pre test dan post test.

Pemberian pretest dilakukan untuk mengetahui pemahaman awal siswa pada kelompok eksprimen maupun pada kelompok kontrol kaitannya dengan materi mata keliling dan luas serta volume bangun ruang.

Observasi dilaksanakan untuk memperoleh data penelitian di lapangan. Adapun observasi untuk melihat aktivitas guru dalam mengajar dan aktivitas belajar siswa selama proses pembelajaran yang menerapkan pendekatan saintifik.

Teknik analisis data yang digunakan menggunakan teknik analisis data statistik deskriptif dan teknik analisis data statistik inferensial. Analisis statistik deskriptif digunakan untuk mendeskripsikan keterlaksanaan proses pembelajaran melaui pendekatan saintifik dan capaian kemampuan berpikir kritis mahasiswa yang dilihat dari hasil pretest dan posttest-nya. Adapun dalam analisis statistik deskriptifnya dilihat dari skor mean, nilai minimum dan nilai maksimum yang dicapai. Pada teknik analisis statistik inferensial yang digunakan adalah analisis parametrik untuk menguji hipotesis. Statistik inferensial yang digunakan yaitu uji independent sample t test pada taraf signifikan 0,05 melalui program SPSS 23.

Data tes yang diperoleh melalui instrumen penelitian diolah dan dianalisis agar hasilnya dapat menjawab pertanyaan peneliti dan menguji hipotesis. Sebelum melakukan uji hipotesis, terlebih dahulu dilakukan pengujian prasyarat analisis data, yaitu uji normalitas dan homogenitas untuk mengetahui apakah data yang diperoleh terdistribusi normal dan mempunyai ragam yang homogen atau tidak.

Pengujian hipotesis dilakukan untuk mengetahui ada perbedaan tingkat berpikir kritis mahasiswa yang diberikan pembelajaran melalui pendekatan saintifik dengan mahasiswa yang diajar dengan cara pembelajaran konvensional. Adapun analisis data yang digunakan untuk menguji hipotesis dalam penelitian ini menggunakan uji Independent Sample T-Test dengan bantuan SPSS dengan taraf kepercayaan 95\% atau dengan tingkat kesalahan ) = 5\% atau 0,05 Adapun kaidah pengujian yang digunakan dalam menguji hipotesis penelitian Independent Sample ttest ini yakni: jika nilai sign (2-tailed), maka Ho diterima (tidak ada perbedaan kemampuan berpikir kritis mahasiwa yang diberikan pembelajaran melalui pendekatan saintifik dengan yang konvensional. Serta jika nilai sign. (2-tailed), maka Ho ditolak (ada perbedaan kemampuan berpikr kritis mahasiswa yang diberikan pembelajaran melalui pendekatan saintifik dengan yang konvensional. 


\section{HASIL DAN PEMBAHASAN}

Pendekatan saintifik dalam pembelajaran merupakan pendekatan yang dijadikan sebagai perlakuan dalam peningkatan hasil belajar siswa. Penerapan pendekatan sanintifik dilakukan sebanyak 4 pertemuan. dan pembelajaran konvensional 4 pertemuan. Sebelum menerapkan perlakuan, terlebih dahulu peneliti mengadakan pretest diluar jadwal pertemuan untuk penelitian. Setelah pertemuan dilakukan sebanyak 4 kali kemudian dilakukan posttest. Sebelum pelaksanaan pendekatan saintifik diterapkan di kelas ekperimen terlebih dahulu dilakukan observasi untuk mengetahui data awal berkaitan dengan kemampuan siswa.

Gambaran hasil belajar awal siswa (prestest) pada kelas eksperimen cenderung berada pada kategori sedang disebabkan terdapat 7 orang siswa dengan persentase $35 \%$ yang memeroleh skor tes berpikir kritis dengan interval skor 47 sampai 69. Gambaran tingkat berpikir kritis mahasiswa pada posttest kelas eksperimen setelah diberikan perlakuan berupa penerapan pendekatan saintifik mengalami peningkatan kemampuan berpikir kritis secara signifikan di mana kecenderungan peningkatan berada pada kategori tinggi sebab ada sebanyak 14 orang siswa dengan persentase $72 \%$ yang memeroleh skor tes hasil belajar dengan interval skor 70 sampai 85 .

Gambaran hasil belajar awal siswa (prestest) pada kelas kontrol berada pada kategori sedang sebab ada sebanyak 6 orang siswa dengan persentase $32 \%$ yang memperoleh skor kemampuan berpikir kritis dengan interval skor 47 sampai 69. Sementara gambaran hasil belajar posttest siswa pada kelas control yang diterapkan melalui pembelajaran konvensional tidak mengalami peningkatan yakni cenderung berada pada kategori sedang sebab ada sebanyak 10 orang siswa dengan persentase $60 \%$ yang memeroleh skor tes hasil belajar dengan interval skor 47 sampai 69.

Nilai rata-rata (mean) dari gain score kemampuan berpikir kritis mahasiswa pada kelas eksperimen (Mean = 0,3830) lebih meningkat dibandingkan kemampuan berpikir kritis mahasiswa pada kelas kontrol (Mean = 0,5750). Dari hasil perbedaan gain score ini membuktikan bahwa perbedaan kemampuan berpikir kritis mahasiswa antara diberikan pembelajaran melalui penerapan pendekatan saintifik dengan yang tidak.

Begitu pula dilihat dari hasil pengujian hipotesis statistic Independent Sample T-Test, diketahui nilai signifikansi $0,014<0,05$ sehingga dari hasil pengujian tersebut juga dapat diketahui bahwa ada perbedaan kemampuan berpikir kritis mahasiswa antara diberikan pembelajaran melalui penerapan pendekatan saintifik dengan yang tidak.
Berdasarkan uji tersebut, baik yang dilihat dari perolehan rata-rata gain score maupun berdasarkan hasil uji hipotesis statistik Independent Sample t-test masingmasing menunjukkan bahwa ada pengaruh terhadap kemampuan berpikir kritis mahasiswa. Letak pengaruhnya yaitu hasil kemampuan berpikir kritis kelas eksperimen lebih tinggi dibandingkan hasil kelas kontrol. Oleh karena itu, dengan melihat selisih hasil belajar kemampuan berpikir kritis mahasiswa kedua kelompok kelas tersebut dapat disimpulkan bahwa ada pengaruh penerapan pendekatan saintifik terhadap kemampuan berpikir kritis mahasiswa PGSD STKIP Kusuma Negara Mata Kuliah Pendidikan Matematika SD 2.

\section{PENUTUP}

\section{Simpulan}

Berdasarkan hasil analisis data disimpulkan bahwa: (1) Penerapan pendekatan saintifik terhadap kemampuan berpikir kritis mahasiswa mengalami peningkatan secara berkelanjutan dengan kategori penilaian baik. (2) kemampuan berpikir kritis berimbas pada Hasil belajar matematika setelah diterapkan pendekatan saintifik dengan kategori tinggi. Begitu juga pada kelas yang menerapkan metode pembelajaran konvensional, juga mengalami peningkatan hasil belajar akan tetapi peningkatannya dengan kategori sedang. (3) Ada pengaruh positif dan signifikan penerapan pendekatan saintifik terhadap kemampuan berpikir kritis mahasiswa PGSD STKIP Kusuma Negara Semester Ganjil 2018/2019.

\section{DAFTAR PUSTAKA}

Ali Hamzah dan Muhlisrarini.2014. Perencanaan dan Strategi Pembelajaran Matematika .Jakarta: Rajawali Pres

Chrisnaji, Banindra Yudha. 2014. Peningkatan Kepercayaan Diri Dan Proses Belajar Matematika Menggunakan Pendekatan Realistik Pada Siswa Sekolah Dasar. Jurnal Prima Edukasia, Volume 2 Nomor 1,2014

Chrisnaji Banindra Yudha. 2018. Peningkatan Motivasi Belajar Mahasiswa Pada Mata Kuliah Konsep Dasar Matematika Melalui Pendekatan Contextual Teaching And Learning. Jurnal Pendidikan Dasar Volume 9, Nomor 1, 2018, Pascasarjana Universitas Negeri Jakarta

Chrisnaji, Banindra Yudha. 2018. Penerapan Game Edukasi Berbasis Android Dan Gambar Bagi Siswa Sekolah Dasar Jurnal Tunas Bangsa Vol. 5, No.2, 2018

Desmita 2010 Psikologi Perkembangan Peserta Didik. (Bandung: PT Remaja Rosdakarya, 
Emelia, Emi. 2007. "Mengajarkan Berpikir Kritis dalam Menulis". Dalam Jurnal Bahasa dan Sastra FPBS UPI, Vol 7 No.2, Oktober 2007

Ennis, R. H. 2011. Critical Thinking. New Jersey. Prentice-Hall Inc.

Fahim, M \& Pezeshki, M. 2012. Manipulating Critical Thinking Skills in Test Taking. International Journal of Education. Vol 4, No 1, Hal 153-160

Facione, N.C. 1995. Critical Thinking And Clinical Judgment: Goals 2000 for nursing science. Paper presented at the Annual Meeting of the Western Institute of Nursing, San Diego, CA.

Inch, E. S., B. Warnick and D. Endres.2006. Critical thinking and communication: the use of reason in argument, Pearson Education Inc, Boston

Ibrahim. 2012. Pembelajaran Matematika Teori dan Aplikasinya. Yoryakarta: SUKA-Press UIN Sunan Kalijaga

Kowiyah. 2012. Kemampuan Berpikir Kritis. Jurnal Pendidikan Dasar, 3(5): 175- 179.

Liliasari. 2005. Membangun Keterampilan Berpikir Manusia Indonesia Melalui Pendidikan Sains. Pidato Pengukuhan Guru Besar dalam Bidang IPA. Bandung : UPI.

Paut, Mega Selvira. 2016. Penerapan Pendekatan Saintifik Pada Siswa Kelas IV Di SD Pujokusuman 1 Yogyakarta The Implementation Of Scientific Approach To Students Grade IV In SD Pujokusuman 1, Yogyakarta. Jurnal Pendidikan Guru Sekolah Dasar Edisi 6 Tahun Ke-5, 2, 511517

Triyaningsih, Anisa Rara. 2015. Pengembangan Pengembangan Perangkat Pembelajaran Dengan Pendekatan Saintifik Pada Materi Trigonometri Untuk Peserta Didik Kelas Xi Sma. Skripsi Tidak Diterbitkan. Yogyakarta: Fkip Uny

Yildirim, B \& Ozkahraman, S. 2011. Critical Thinking in Nursing Process and Education. International Journal of Humanities and Social Science. Vol 1, No 13, Hal 257- 262

Yani, Ahmad. 2014. Mindset Kurikulum 2013. Bandung: CV. Alfabeta 